\title{
7
}

\section{The Nation State and Knowledge Capital}

\begin{abstract}
This chapter analyses how a Nation State can contribute to enhanced wellbeing. It begins with its responsibility to act on behalf of citizens as wise custodian of the market economy and welfare state within its borders. This requires central government to adopt an integrated and balanced approach to all its economic and welfare policies. The second half of the chapter focuses on the concept of knowledge capital as a driver of wellbeing. Knowledge creation can be an economic public good, which creates a distinctive opportunity for a wellfunctioning state to contribute to expanded capabilities for wellbeing through policies that foster the growth and use of knowledge. Knowledge is essential to the operations of the Nation State, whose civil service can offer a specialist capability for creating, collating, synthesising, utilising and disseminating knowledge capital for the common good.
\end{abstract}

Keywords Knowledge capital $\bullet$ Public policy $\bullet$ Welfare state $\bullet$ Endogenous growth $\bullet$ Civil service

Readers may be surprised that this book has not turned to the Nation State, and hence to central government policy, until Chap. 7 . The delay is due to the core presumption in wellbeing economics that persons are able to exercise initiative in promoting personal wellbeing and the wellbeing of others through individual effort, co-creation in households and families, collaboration in community 
institutions, co-operation in the market economy and co-production of local government services. It has been important to analyse these diverse capabilities before analysing distinctive contributions of central government to enhanced wellbeing.

A useful introduction to this chapter's major themes is the theory of the Nation State presented by Max Weber (1919) just after World War I. Weber argued that the defining characteristic of a State is its monopoly on the legitimate use of physical force within a given territory, so that individuals or organisations may exercise force only to the extent permitted by the State. As persons seek to lead valued lives, conflicts arise. Nevertheless, all should be able to presume that it is illegitimate for these conflicts to result in violence. ${ }^{1}$ Hence, the State accepts responsibility for maintaining law and order, and so provides trustworthy institutions for dispute resolution such as the armed forces, the police, the judiciary, the prisons and arbitration tribunals.

This theory of the Nation State is an application of Proposition 16: Good government can develop distinctive capabilities for managing the provision of certain types of goods and services, especially those with externalities or the characteristics of an economic public good. In this case, the economic public good being provided by the government is the maintenance of the rule of law (Heckman et al. 2010; Xu 2011).

Another application of Proposition 16 concerns the market economy. The previous chapter observed that markets need rules to work well. The London Stock Exchange, for example, maintains a Rulebook for the operation of that sophisticated market that runs to 98 pages (London Stock Exchange 2018). More generally, one of the key responsibilities of the Nation State is to define rules for the operation of markets under its jurisdiction.

A further application concerns the welfare state. Chapter 5 commented that it is reasonable for public policy to be designed so that all persons can access life-changing services such as housing, education and health independently of their household income. Public policy is also designed to provide a measure of social security to all citizens. The Nation State is responsible for designing and implementing these public policies. The chapter begins by considering these responsibilities, arguing that the Nation State acts as custodian of the market economy and the welfare state, taken together.

To fulfil its diverse roles, a well-functioning state must create, collate, synthesise, utilise and disseminate considerable amounts of knowledge. Further, existing knowledge and the discovery of new knowledge can have the characteristics of an economic public good. Central government therefore has a distinctive role in managing knowledge provision. Consequently, this chapter 
discusses the contribution of knowledge capital in the wellbeing economics framework. It explains its importance in economic models of growth and how governments address the issues raised by its economic public good characteristics. The chapter then ends with a discussion of the civil service's specialist capability for working with knowledge for the common good, before a brief conclusion.

\section{Custodian of the Market Economy and Welfare State}

For most of the nineteenth and early twentieth centuries, the general disposition in public policy towards the wellbeing of citizens was based on "individualism and laissez-faire" (Keynes 1926, p. 272). This held that a Nation State might offer some limited remedies for addressing deserving cases of extreme poverty (the English Poor Laws, e.g.; see Boyer 1990), but otherwise outcomes were best left to individual enterprise and civil society operating within the market economy.

That disposition changed in the 1930s and 1940s. The Great Depression demonstrated that individual effort under laissez-faire policies is not always able to achieve reasonable standards of living, while World War II led to new understandings of how government action might enhance citizen wellbeing. International consensus in support of this change became sufficiently strong for the Universal Declaration of Human Rights, which was adopted by the United Nations General Assembly on 10 December 1948, to record social security as a universal right (Article 22):

Everyone, as a member of society, has the right to social security and is entitled to realization, through national effort and international co-operation and in accordance with the organization and resources of each State, of the economic, social and cultural rights indispensable for his dignity and the free development of his personality.

In the United Kingdom, this transition from individualism and laissez-faire to what might be termed liberal collectivism (Cutler et al. 1986, Chap. 1) is evident in two landmark publications: Keynes (1936) and Beveridge (1942). The former was written in response to the Great Depression. Triggered by the New York stock market crash in August 1929, the Depression was transmitted to other countries as a result of substantial falls in world trade (Hamilton 
1988; Eichengreen and Temin 2000). The volume of UK exports, for example, fell by more than a third between 1929 and 1931 (Maddison 1962, Table 25, p. 186).

The impact on the UK economy was not as severe as in the United States, but unemployment was already high in 1929 at 1.5 million, which was 7.3 per cent of the labour force. Unemployment peaked at 3.4 million in 1932, and remained above 1.8 million until 1937 (Middleton 2010, p. 417, citing Feinstein 1972). Of those unemployed in 1929, 10.7 per cent had been without a job for more than a year, but this figure had reached 27.1 per cent in 1937 (Crafts 1989, p. 247).

The laissez-faire policy response was to wait for wages to fall in order to restore full employment. Average annual earnings in the United Kingdom did indeed decline, by 8.7 per cent between 1929 and 1933 (Clark 2018). The retail price index, however, fell by a greater amount ( 14.4 per cent), so that the real wage rate (i.e., the real purchasing power of wages, defined as money wages divided by the price level) actually increased; see also Beenstock and Warburton (1986) and Hart (2001).

John Maynard Keynes wrote The General Theory of Employment, Interest and Money against that background (Skidelsky 1992). He developed two objections to the classical theory that high unemployment could always be addressed by lower wages. The first was that workers might reasonably resist a reduction in their individual wages, even if willing to accept a fall in real spending power imposed on all workers through an increase in consumer prices. That behavioural assumption was of its time and place and need not detain us any further. Keynes described his second objection as more fundamental and the subject of his new theory (Keynes 1936, p. 13):

There may exist no expedient by which labour as a whole can reduce its real wage to a given figure by making revised money bargains with the entrepreneurs. We shall endeavour to show that primarily it is certain other forces which determine the general level of real wages. The attempt to elucidate this problem will be one of our main themes.

Keynes called his theory the principle of effective demand. Under certain circumstances, the level of employment becomes constrained by inadequate demand for the purchase of goods and services (Davidson 1998). During such a period, reduced money wages cannot achieve full employment, because lower wages do not stimulate demand. ${ }^{2}$ Individuals are powerless, but the Nation State can restore balance by managing effective demand. Keynes (1936, p. 380) rec- 
ognised such a responsibility meant enlarging the functions of central government, which he defended as necessary to protect the market economy and to support individual initiative within its system.

The second landmark publication was commissioned during World War II from a committee of civil servants headed by Sir William Beveridge as the independent chair (Abel-Smith 1992). Beveridge took for granted that the State had major responsibility for keeping unemployment to a minimum (Beveridge 1942, par. 22 and par. 440). He drew on surveys that had been made of British poverty to argue that full employment is insufficient for the abolition of want in the community. Instead, a plan for social security was required with two elements: (1) "provision against interruption and loss of earning power"; and (2) "adjustment of incomes, in periods of earning as well as in interruption of earning, to family needs" (idem, par. 12 and par. 13).

Beveridge adopted the principle that "social security must be achieved by cooperation between the State and the individual" and "should not stifle incentive, opportunity, responsibility” (idem, par. 9). In that partnership, the State's specific contribution is to use its authority to collect compulsory levies so that a system of social insurance could be implemented. This expansion in the role of government was justified in Beveridge's view by "the general tendency of public opinion" (idem, par. 26):

After a trial of a different principle, it has be found to accord best with the sentiments of the British people that in insurance organised by the community by use of compulsory powers each individual should stand on the same terms; none should claim to pay less because he is healthier or has more regular employment. In accord with that view, the proposals of the Report mark another step forward to the development of State insurance as a new type of human institution...

The Beveridge Report became a cornerstone of the British welfare state (Hill 1993; Lowe 2004; Glennerster 2007; Fraser 2017, Chap. 9; Renwick 2017). The Education Act 1944 provided for free secondary education and set the schoolleaving age at 15. The Family Allowances Act 1945, the National Insurance Act 1946 and the National Assistance Act 1948 created a comprehensive system of social security. The National Health Service Act 1946, with similar legislation for Scotland and Northern Ireland in 1947 and 1948, provided a system of medical care without user charges. The New Towns Act 1946 and the Town and Country Planning Act 1947 supported major post-war programmes of new housing.

It is beyond the scope of this book to trace further developments in the UK welfare state since the 1940 s, or to discuss welfare policies in other countries. ${ }^{3}$ 
The key point is that it became generally accepted that wise management of the market economy and welfare state by central government has the potential to improve wellbeing beyond what individuals and civil society can achieve. This observation is expressed in the following proposition.

Proposition 19 The Nation State can contribute to expanded capabilities for wellbeing by acting on behalf of citizens as wise custodian of the market economy and welfare state within its borders.

There are intense debates in every country about what "wise custodian" might mean in this proposition, or even whether central government can perform such a role adequately. These debates can be an indicator of a democracy's good health, since they address important questions about the kinds of lives that communities have reason to value, reflecting different histories and aspirations in each country. Proposition 19 does not address those debates, but conveys a key idea in the wellbeing economics framework, which is that this function of government is a single role. The Nation State is custodian of the market economy and the welfare state, taken together.

This insistence on an integrated approach is necessary because the market economy and the welfare state are not isolated from each other. To illustrate, recall the strong tendency identified in Chap. 5 for resources in the market economy to flow towards high-wealth households. If housing, education and health services were provided on a laissez-faire basis within the market economy, then this tendency would result in low-wealth households having restricted access to these services. This would reduce capabilities for wellbeing. It would also restrict the ability of low-wealth households to invest in human capital, which would limit labour productivity and so damage economic performance. Policies of the welfare state seek to prevent this by aiming to making certain standards of housing, education and healthcare (determined by social expectations and budget constraints) available to the whole population.

Similarly, economic performance impacts on the wellbeing functions of the welfare state. Cutler et al. (1986, p. 18) point out, for example, that the Beveridge Report assumed that jobs would pay decent wages, so that a person in employment could be presumed capable of achieving a satisfactory standard of living. As discussed in Chap. 5, this presumption is untenable given that more than one in seven jobs in the UK pay below the voluntary living wage. The failure of the market economy to create decent jobs puts pressure on the housing, education, health and social security systems of the welfare state. 
Proposition 19 therefore requires a unified stance in public policies affecting the market economy and welfare state. In particular, it rejects the view, already criticised in Chap. 1, that "growth is the essential foundation of all our aspirations" (Cameron 2010, par. 4). Instead, an integrated and balanced approach is required across all policy areas.

\section{Knowledge Capital}

It has long been recognised that a Nation State must adopt a sophisticated approach to how it obtains and uses knowledge. Consider the Haldane Report, for example, which was commissioned as a guide for reform of the civil service after World War I. It identified four main principles for reform, the first of which emphasised knowledge (Ministry of Reconstruction 1918, par. 56):

Further provision is needed in the sphere of civil government for the continuous acquisition of knowledge and the prosecution of research, in order to furnish a proper basis for policy.

In the private sector, knowledge is recognised as a fundamental factor driving growth in material living standards. Recall that Solow's (1956) neoclassical growth model explains how growth in a country's average standard of living depends on technological progress. The contributions to technological progress were not explored, which was a weakness. Paul Romer $(1986,1990)$ therefore initiated a research programme to fill the gap. He accepted Solow's insights that the best measure of technological progress is labour productivity (i.e., the average value of output produced per hour of work) and that this depends on the stock of physical capital. He then added the idea that labour productivity also depends on the stock of knowledge, which increases through the dedicated activities of specialist workers engaged in research and development.

Romer's insight created endogenous growth theory, so-called because it explains technological progress within the model (Romer 1994; Aghion and Howitt 1998). The theory analyses a trade-off, since workers engaged in research and development are not available for other production. Thus, the creation of new knowledge has an opportunity cost in the form of foregone benefits that could have been realised from shifting the knowledge workers to the production of other goods and services. Balancing the costs and benefits of this trade-off 
allows the model to analyse an economy's equilibrium rate of technological progress, which determines its rate of economic growth.

Romer assumed that new knowledge created at any time is proportional to the amount of existing knowledge, depending on how many workers are engaged in research and development (see also Aghion and Howitt 1992). This produced the result that economic growth is higher with more knowledge workers, but Jones (1995a, 1995b) pointed out that this result is incompatible with experience. Large increases in the number of researchers over decades have not resulted in anything like comparable increases in economic growth rates. Consequently, as Ang and Madsen (2011, p. 1360) observe:

Following Jones's (1995b) critique of the predictions of the first-generation endogenous growth models of Romer (1990) and Aghion and Howitt (1992), a positive relationship between the levels of $\mathrm{R} \& \mathrm{D}$ and productivity growth is generally no longer accepted as an empirical regularity in the growth literature.

Jones (1995a) suggested instead that the theory should recognise that research involves some wasted effort. He assumed that researchers find it increasingly hard to create new knowledge (implying more and more wasted effort) as the stock of knowledge expands. This assumption reproduced many features of the neoclassical growth model. Neither efforts to reduce wasted research or policies to increase the number of research workers could increase a country's rate of economic growth (Jones and Vollrath 2013, p. 106).

A second generation of endogenous growth theory was then introduced by scholars such as Young (1998), Howitt (1999), Ha and Howitt (2007) and Ang and Madsen (2011). They agreed there is some wasted effort in creating knowledge, but did not accept that this waste increases as knowledge expands. Instead, the new model assumed that the effectiveness of research effort diminishes with scale, since the effort must be spread over a greater variety of products. This restored Romer's hypothesis that knowledge increases in proportion to its current level, but the relationship now depended on the proportion of the labour force (not the absolute number) devoted to the task of research and development.

In all these models, knowledge acts as a capital stock that enhances labour productivity in providing market goods and services. ${ }^{4}$ Unlike physical or natural capital, however, knowledge capital does not depend on material resources. It can also have the characteristics of an economic public good (World Bank 1998, pp. 131-133; Stiglitz 1999), which gives rise to important implications for wellbeing. 


\section{Knowledge as an Economic Public Good}

Consider two passenger flights crossing the Atlantic at the same hour. The flights require two planes, each of which represents a separate investment in physical capital. They also require separate flight crews, each with skilled human capital acquired through training and experience. In contrast, the two flights use the same knowledge capital. Both planes were designed using the same laws of aerodynamics, and the actions of pilots and cabin crew in both planes are guided by the same knowledge about flight safety.

Economists have long studied how advancing knowledge is embedded in physical capital (Solow 1962) and how access to global knowledge depends on human capital (Nelson and Phelps 1966). A feature of knowledge capital is that the same knowledge can be incorporated into any number of items of physical capital, and can be used simultaneously by any number of persons with the necessary human capital. In the language of economics, knowledge is non-rival in consumption (Stiglitz 1999).

This property means that the discovery and use of knowledge can be hugely beneficial to wellbeing. Discoveries can be used simultaneously by millions, even billions, of people to enhance wellbeing. "In short, knowledge gives people greater control over their destinies" (World Bank 1998, p. 2). Nor are there physical limits on the accumulation of a non-rival, non-material good like knowledge (Romer 1990, p. S74).

Further, production systems that use knowledge capital as an input exhibit the property of increasing returns to scale (Romer 1990, pp. S75-S76). This means that if all inputs into the production system double, including non-rival knowledge, then the level of output more than doubles. This is the property that gives rise to the result in endogenous growth theory that a higher rate of knowledge creation can lead to a higher rate of economic growth.

These observations offer a potential path for addressing the crucial question of how it might be feasible for humanity to raise the wellbeing of people in poverty across the globe, while respecting the planet's absolute limits to material consumption. Conceptually, this might be achieved, at least in part, by technological progress that substitutes (immaterial) knowledge capital for (material) physical and natural capital in economic production systems. If this path is to be followed, however, there is a critical problem to be addressed.

Once new knowledge is put to use, it is often impossible to prevent others from putting the same idea into practice for themselves. There are exceptions. A firm may be able to keep new knowledge secret until market dominance has 
been achieved. A new technology might require such large physical capital investment, or such specialist human capital, that only a few firms can take advantage of the discovery. Nevertheless, without public policies to address this issue, new knowledge often has the second characteristic of an economic public good-it is non-excludable. ${ }^{5}$

This characteristic severely weakens the incentive for efforts to discover new knowledge. A firm might spend large sums to undertake original research. It might then devote more human and financial resources to develop a discovery into a commercial product. These investments would not be recouped, however, if other firms are able simply to copy the idea without incurring the same research and development costs.

Consequently, investment in creating new knowledge may be valuable for wellbeing, but impossible for market firms to finance. This creates a distinctive opportunity for good government to contribute to wellbeing by addressing this conundrum, as recorded in Proposition 20.

Proposition 20 Knowledge capital has the properties of an economic public good, so that Nation States can contribute to enhanced wellbeing by fostering the growth and use of knowledge.

A straightforward example is to create laws that protect intellectual property through copyright, patents and other legal instruments (World Bank 1998, pp. 16-17). These laws typically require details of a discovery to be placed on public record in return for the right to exclude others from using the new knowledge for a fixed period of time. The length of the exclusion period aims to balance the incentive benefits of rewarding successful efforts to create new knowledge with the wellbeing benefits of discoveries being made widely available.

To be effective, domestic laws must be reinforced by international agreements for the protection of intellectual property, taking into account different capabilities of developed and developing countries (Schneider 2005). The ability to make such agreements is an example of what this book terms diplomatic capital, which will be discussed in the following chapter.

Another example of Proposition 20 is the smart specialisation concept for regional development, mentioned in the previous chapter (Foray 2006, 2015, Foray et al. 2009; OECD 2013; McCann and Ortega-Argilés 2015). Creation of new knowledge is a global enterprise (Stiglitz 1999). Hence, it is sensible for regions to focus their research and development efforts on niches in the global innovation system where they have particular strengths and opportunities. Central government can assist by funding the design of generic 
institutional processes and analytical tools for regions to use for determining their own capabilities for smart specialisation.

\section{The Civil Service, Knowledge and Capabilities}

The public sector is a significant part of a national economy. In September 2017, there were 5.5 million people employed in the UK public sector, which represented 17.1 per cent of all employed people in the country (ONS 2017). Figure Fig. 7.1 shows how the distribution of this employment by industry, with the three largest concentrations being in the National Health Service, in education and in public administration.

The civil service is a small but important subset of the public sector. It has been significantly reduced in the United Kingdom; see Fig. Fig. 7.2. At the beginning of the global financial crisis in September 2007, the seasonally adjusted full-time equivalent number in the civil service was 495,000. This number was reduced to its lowest level since World War II by the end of 2011 (HM Government 2012b, p. 9). In September 2017, it had been further reduced to 392,000 , which was 20.8 per cent lower than a decade earlier.

The civil service offers a specialist service within the public sector (NAO 2017). Its primary responsibility is to help the government of the day, which it has been doing on a professional basis in the United Kingdom since the middle of the nineteenth century (Northcote and Trevelyan 1854, p. 3):

It may safely be asserted that, as matters now stand, the Government of the country could not be carried on without the aid of an efficient body of permanent officers, occupying a position duly subordinate to that of the Ministers who are directly responsible to the Crown and to Parliament, yet possessing sufficient independence, character, ability, and experience to be able to advise, assist, and, to some extent, influence, those who are from time to time set over them.

Organised into departments, agencies and non-departmental government bodies, the civil service has three specific roles: operational delivery, advising on policy and supporting Ministers, and implementing programmes and projects (HM Government 2012a, pp. 8-9). The first is the largest duty; more than 70 per cent of all civil servants are employed in the delivery departments and their agencies of Work and Pensions, HM Revenue and Customs, Justice, Defence and the Home Office (ONS 2017, Table 9). 


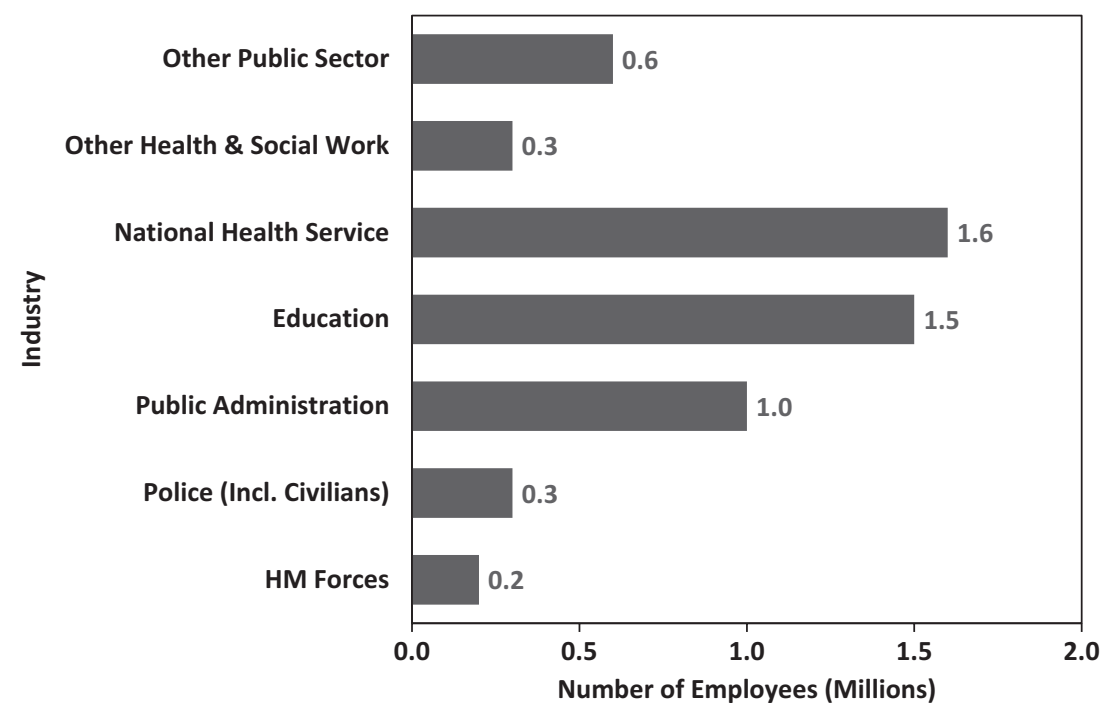

Fig. 7.1 Number of people employed in the public sector by industry, seasonally adjusted, United Kingdom, September 2017. (Source: ONS 2017, Table 2)

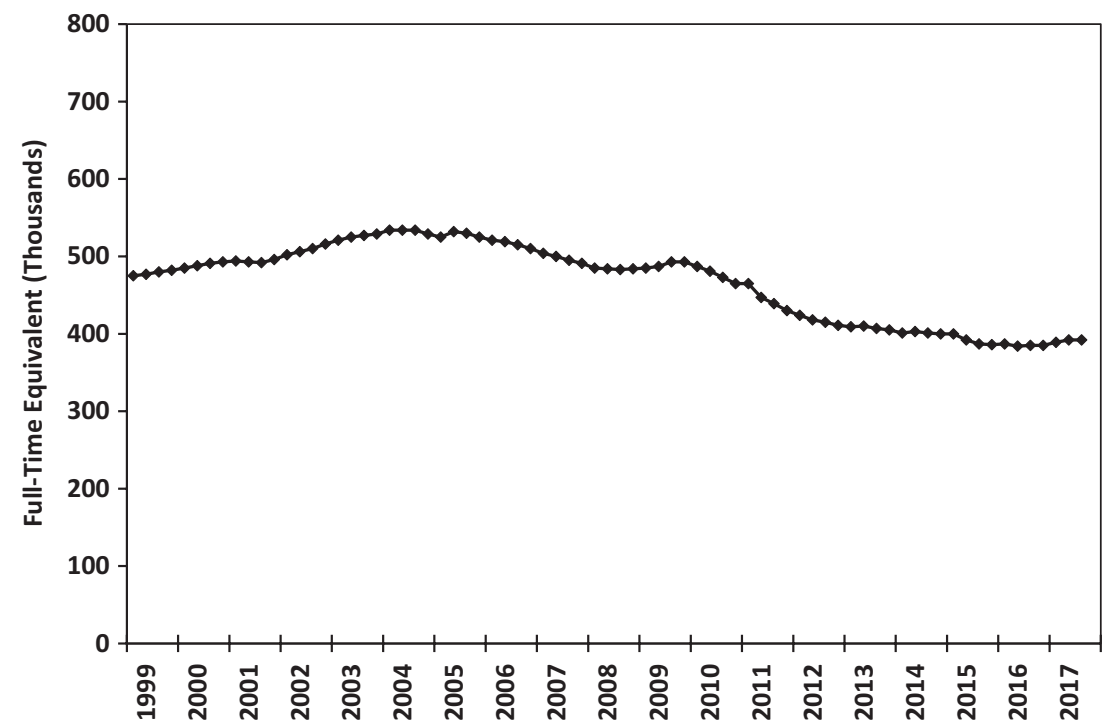

Fig. 7.2 Number of people employed in the civil service, full-time equivalent seasonally adjusted, quarterly, United Kingdom, 1999(1)-2017(3). (Source: ONS 2017, Table 1) 
The distinctive contribution of the civil service is its capability for working with knowledge as a public service on behalf of the Nation State. This is reflected in the final proposition of this chapter.

Proposition 21 The civil service can offer a specialist capability for creating, collating, synthesising, utilising and disseminating knowledge capital for the common good.

Undertaking knowledge work for the public good requires certain values to be observed. The Constitutional Reform and Governance Act 2010 therefore requires civil servants to carry out their duties with integrity and honesty, and with objectivity and impartiality, which are defined in the Civil Service Code: ${ }^{6}$

- "integrity" is putting the obligations of public service above your own personal interests

- "honesty" is being truthful and open

- "objectivity" is basing your advice and decisions on rigorous analysis of the evidence

- "impartiality" is acting solely according to the merits of the case and serving equally well governments of different political persuasions

As the Code observes, these core values support good government. They are essential if citizens are to trust knowledge work undertaken by civil servants for the common good. The importance of this feature of good government has led to recent recommendations that public sector departments and agencies should adopt transparent practices so that people outside government can understand how evidence is used in policy decision, implementation and evaluation (Rutter and Gold 2015; Brown 2016).

\section{Conclusion}

This chapter has focussed on the Nation State, beginning with its contribution to expanded capabilities by acting as wise custodian of the market economy and welfare state within its borders. This requires an integrated and balanced approach to all economic and welfare policies. Policy cannot be satisfied with promoting economic growth for its own sake; it must pay attention to how the economy is growing and the impacts this is having on the wellbeing of different 
parts of the national population. In particular, how is policy contributing to expanding the capabilities of persons to lead the kinds of lives they value, and have reason to value?

The second half of the chapter has been structured around the concept of knowledge capital. Discovery of new knowledge has long been recognised as a fundamental driver of economic and social wellbeing. Further, because existing knowledge does not depend on material resources and is non-rival in consumption, knowledge accumulation has great potential for contributing to enhanced wellbeing while respecting the material limits of the planet.

Knowledge, however, is often non-excludable, so that knowledge creation is an economic public good. This creates a distinctive opportunity for Nation States to contribute to enhanced wellbeing through policies that foster the growth and use of knowledge. At the same time, knowledge is essential to the operations of the Nation State, whose civil service can offer a specialist capability for creating, collating, synthesising, utilising and disseminating knowledge capital for the common good.

Some critical problems facing humanity clearly require actions that go beyond state borders. Pressing examples include persistent poverty in some of the world's regions and global climate change. Chap. 8 therefore analyses ways in which the global community can work together to enhance wellbeing on an international scale.

\section{Notes}

1. As Chap. 4 observed, one of the horrors of institutional racism is that some citizens are unable to make this presumption because of the colour of their skin (Coates 2015; Eddo-Lodge 2017).

2. See Dalziel and Lavoie (2003) for a presentation of this theory in a labour market diagram. Note that Keynes does not imply that unemployment is always caused by inadequate demand; the classical theory has a place in explaining some episodes of high unemployment (Dalziel 1993). Boyer (2012) and Krugman (2012) are examples of analyses that drew on the theory of effective demand to critique the austerity policies implemented after the global financial crisis.

3. Pedersen (2018) observes that the welfare state was neither a British invention nor a British product.

4. Early uses of the phrase knowledge capital were by Griliches (1979) and Nelson (1982).

5. Recognising the exceptions, as well as the practice of creating legal mechanisms to make some forms of new knowledge a proprietary asset, economists observe that 
knowledge is not necessarily a strict economic public good. Examples of alternative phrases to describe knowledge include "a partially excludable good" (Romer 1990, section II), having "spillover benefits" (World Bank 1998, p. 130) or "an impure public good" (Stiglitz 1999, p. 310). This does not affect this section's argument.

6. Accessed 23 January 2018 at https://www.gov.uk/government/publications/civil-service-code/the-civil-service-code.

\section{References}

Abel-Smith, Brian. 1992. The Beveridge Report: Its Origins and Outcomes. International Social Security Review 45 (1-2): 5-16.

Aghion, Philippe, and Peter Howitt. 1992. A Model of Growth through Creative Destruction. Econometrica 60 (2): 323-351.

- 1998. Endogenous Growth Theory. Cambridge, MA: MIT Press.

Ang, James, and Jakob Madsen. 2011. Can Second-Generation Endogenous Growth Models Explain the Productivity Trends and Knowledge Production in the Asian Miracle Economies? Review of Economics and Statistics 93 (4): 1360-1373.

Beenstock, Michael, and Peter Warburton. 1986. Wages and Unemployment in Interwar Britain. Explorations in Economic History 23 (2): 153-172.

Beveridge, William H. B. 1942. Social Insurance and Allied Services: Report by Sir William Beveridge. Report presented to Parliament by Command of His Majesty. London: His Majesty's Stationery Office.

Boyer, George R. 1990. An Economic History of the English Poor Law, 1750-1850. Cambridge: Cambridge University Press.

Boyer, Robert. 2012. The Four Fallacies of Contemporary Austerity Policies: The Lost Keynesian Legacy. Cambridge Journal of Economics 36 (1): 283-312.

Brown, Tracey. 2016. Transparency of Evidence: An Assessment of Government Policy Proposals May 2015 to May 2016. Report of a research project by Sense about Science, the Institute for Government and the Alliance for Useful Evidence, funded by the Nuffield Foundation. London: Sense about Science.

Cameron, Rt. Hon. David. 2010. PM Speech on Wellbeing A Transcript of a Speech Given by the Prime Minister on 25 November 2010. https://www.gov.uk/government/speeches/pm-speech-on-wellbeing.

Clark, Gregory. 2018. What Were the British Earnings and Prices Then? (New Series). Measuring Worth database accessed 26 January 2018 at www.measuringworth.com/ ukearncpi/.

Coates, Ta-Neshi. 2015. Between the World and Me. Melbourne: Text Publishing.

Crafts, Nicholas F. R. 1989. Long-Term Unemployment and the Wage Equation in Britain, 1925-1939. Economica 56 (222): 247-254.

Cutler, Tony, Karel Williams, and John Williams. 1986. Keynes, Beveridge and Beyond. London: Routledge. 
Dalziel, Paul. 1993. Classical and Keynesian Unemployment in a Simple Disequilibrium AS-AD Framework. Australian Economic Papers 32 (60): 40-52.

Dalziel, Paul, and Marc Lavoie. 2003. Teaching Keynes's Principle of Effective Demand Using the Aggregate Labour Market Diagram. Journal of Economic Education 34 (4): 333-340.

Davidson, Paul. 1998. Post Keynesian Employment Analysis and the Macroeconomics of OECD Unemployment. Economic Journal 108 (448): 817-831.

Eddo-Lodge, Reni. 2017. Why I'm No Longer Talking to White People About Race. London: Bloomsbury Circus.

Eichengreen, Barry, and Peter Temin. 2000. The Gold Standard and the Great Depression. Contemporary European History 9 (2): 183-207.

Feinstein, Charles H. 1972. National Income, Expenditure and Output of the United Kingdom, 1855-1965. Cambridge: Cambridge University Press.

Foray Dominique. 2006. Globalization of R\&D: Linking Better the European Economy to "Foreign" Sources of Knowledge and Making EU a More Attractive Place for R\&D Investment. Knowledge Economists Policy Brief No. 1. http://ec.europa.eu/ invest-in-research/monitoring/knowledge_en.htm. Accessed 10 Jan 2018.

- 2015. Smart Specialisation: Opportunities and Challenges for Innovation Policy. London: Routledge.

Foray Dominique, Paul A. David and Bronwyn Hall. 2009. Smart Specialisation - The Concept. Knowledge Economists Policy Brief No. 9. http://ec.europa.eu/invest-inresearch/monitoring/knowledge_en.htm. Accessed 10 Jan 2018.

Fraser, Derek. 2017. The Evolution of the British Welfare State: A History of Social Policy since the Industrial Revolution. 5th ed. London: Palgrave Macmillan.

Glennerster, Howard. 2007. British Social Policy: 1945 to the Present. 3rd ed. Oxford: Blackwell.

Griliches, Zvi. 1979. Issues in Assessing the Contribution of Research and Development to Productivity. Bell Journal of Economics 10 (1): 92-116.

Ha, Joonkyung, and Peter Howitt. 2007. Accounting for Trends in Productivity and R\&D: A Schumpeterian Critique of Semi-Endogenous Growth Theory. Journal of Money, Credit and Banking 39 (4): 733-744.

Hamilton, James D. 1988. Role of the International Gold Standard in Propagating the Great Depression. Contemporary Economic Policy 6 (2): 67-89.

Hart, Robert A. 2001. Hours and Wages in the Depression: British Engineering, 1926-1938. Explorations in Economic History 38 (4): 478-502.

Heckman, James J., Robert L. Nelson, and Lee Cabatingan, eds. 2010. Global Perspectives on the Rule of Law. Abingdon/New York: Routledge.

Hill, Michael. 1993. The Welfare State in Britain: A Political History since 1945. Cheltenham: Edward Elgar.

HM Government. 2012a. The Civil Service Reform Plan. London: Cabinet Office. . 2012b. The Context for Civil Service Reform. London: Cabinet Office. 
Howitt, Peter. 1999. Steady Endogenous Growth with Population and R\&D Inputs Growing. Journal of Political Economy 107 (4): 715-730.

Jones, Charles I. 1995a. R \& D Models of Economic Growth. Journal of Political Economy 103 (4): 759-784.

. 1995b. Time Series Tests of Endogenous Growth Models. Quarterly Journal of Economics 110 (2): 495-525.

Jones, Charles I., and Dietrich Vollrath. 2013. Introduction to Economic Growth. 3rd ed. New York: W. W. Norton.

Keynes, John Maynard. 1926. The End of Laissez-Faire. Pamphlet published by the Hogarth Press, reprinted in and cited from Chapter 2 in Donald Moggridge, Ed. The Collected Writings of John Maynard Keynes, Volume IX: Essays in Persuasion, pp. 272-294. London: Macmillan for the Royal Economic Society, 1972.

. 1936. The General Theory of Employment, Interest and Money, reprinted in and cited from Donald Moggridge, Ed. The Collected Writings of John Maynard Keynes, Volume VII: The General Theory. London: Macmillan for the Royal Economic Society, 1973.

Krugman, Paul R. 2012. End This Depression Now! New York: W. W. Norton.

London Stock Exchange. 2018. Rules of the London Stock Exchange, Effective Date 3 January. www.londonstockexchange.com/traders-and-brokers/rules-regulations/ rules-lse.pdf. Accessed 7 Feb 2018.

Lowe, Rodney. 2004. The Welfare State in Britain since 1945. 3rd ed. Basingstoke: Palgrave.

Maddison, Angus. 1962. Growth and Fluctuation in the World Economy, 1870-1960. Banca Nazionale del. Lavoro Quarterly Review 15 (61): 127-195.

McCann, Philip, and Raquel Ortega-Argilés. 2015. Smart Specialization, Regional Growth and Applications to European Union Cohesion Policy. Regional Studies 49 (8): 1291-1302.

Middleton, Roger. 2010. British Monetary and Fiscal Policy in the 1930s. Oxford Review of Economic Policy 26 (3): 414-441.

Ministry of Reconstruction. 1918. Report of the Machinery of Government Committee. Report presented to Parliament by Command of His Majesty. London: His Majesty's Stationery Office.

NAO. 2017. Capability in the Civil Service. Report by the Comptroller and Auditor General, HC 919, Session 2016-2017. London: National Audit Office.

Nelson, Richard R., and Edmund S. Phelps. 1966. Investment in Humans, Technological Diffusion, and Economic Growth. American Economic Review 56 (1/2): 69-75.

Nelson, Richard R. 1982. The Role of Knowledge in R\&D Efficiency. Quarterly Journal of Economics 97 (3): 453-470.

Northcote, Stafford H., and Charles E. Trevelyan. 1854. On the Organisation of the Permanent Civil Service. Report presented to both Houses of Parliament by Command of Her Majesty. London: Her Majesty's Stationery Office. 
OECD. 2013. Innovation-driven Growth in Regions: The Role of Smart Specialisation. Paris: Organisation for Economic Cooperation and Development.

ONS. 2017. Public Sector Employment, UK: September 2017. Statistical Bulletin released 13 December, Office for National Statistics.

Pedersen, Susan. 2018. One-Man Ministry. London Review of Books 40 (3): 3-6.

Renwick, Chris. 2017. Bread for All: The Origins of the Welfare State. London: Allen Lane. Romer, Paul M. 1986. Increasing Returns and Long-Run Growth. Journal of Political Economy 94 (5): 1002-1037.

- 1990. Endogenous Technological Change. Journal of Political Economy 98 (5 Part 2): S71-S102.

- 1994. The Origins of Endogenous Growth. Journal of Economic Perspectives 8 (1): 3-22.

Rutter, Jill and Jen Gold. 2015. Show Your Workings: Assessing How Government Uses Evidence To Make Policy. London: Institute for Government.

Schneider, Patricia Higino. 2005. International Trade, Economic Growth and Intellectual Property Rights: A Panel Data Study of Developed and Developing Countries. Journal of Development Economics 78 (2): 529-547.

Skidelsky, Robert. 1992. John Maynard Keynes: The Economist as Saviour, 1920-1937. London: Macmillan.

Solow, Robert M. 1956. A Contribution to the Theory of Economic Growth. Quarterly Journal of Economics 70 (1): 65-94.

- 1962. Technical Progress, Capital Formation, and Economic Growth. American Economic Review 52 (2): 76-86.

Stiglitz, Joseph E. 1999. Knowledge as a Global Public Good. In Global Public Goods: International Cooperation in the 21st Century, ed. Inge Kaul, Isabelle Grunberg and Marc Stern, 308-326. Oxford: Oxford University Press.

Weber, Max. 1919. Politics as a Vocation. Lecture delivered in Munich on 28 January 1919. Translated and edited by Dagmar Waters, Benjamin Elbers and Tony Waters, published as chapter 7 in Tony Waters and Dagmar Waters, Eds. Weber's Rationalism and Modern Society: New Translations on Politics, Bureaucracy, and Social Stratification. New York: Palgrave Macmillan, pp. 129-198.

World Bank. 1998. World Development Report 1998/1999: Knowledge for Development. New York: Oxford University Press.

$\mathrm{Xu}$, Guangdong. 2011. The Role of Law in Economic Growth: A Literature Review. Journal of Economic Surveys 25 (5): 833-871.

Young, Alwyn. 1998. Growth without Scale Effects. Journal of Political Economy 106 (1): 41-63. 
Open Access This chapter is licensed under the terms of the Creative Commons Attribution 4.0 International License (http://creativecommons.org/licenses/by/4.0/), which permits use, sharing, adaptation, distribution and reproduction in any medium or format, as long as you give appropriate credit to the original author(s) and the source, provide a link to the Creative Commons license and indicate if changes were made.

The images or other third party material in this chapter are included in the chapter's Creative Commons license, unless indicated otherwise in a credit line to the material. If material is not included in the chapter's Creative Commons license and your intended use is not permitted by statutory regulation or exceeds the permitted use, you will need to obtain permission directly from the copyright holder.

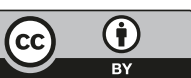

